\title{
Analytical Results of a Long-Term Aquifer Test Conducted near the Rio Grande, Albuquerque, New Mexico
}

With a Section on

Piezometric-Extensometric Test Results

\section{U.S. Department of the Interior \\ U.S. Geological Survey}

Water-Resources Investigations Report 00-4291

Prepared in cooperation with the

City of Albuquerque Public Works Department, Water Resources Management 



\section{Analytical Results of a Long-Term Aquifer Test Conducted near the Rio Grande, Albuquerque, New Mexico By Condé R. Thorn}

With a Section on Piezometric-Extensometric Test Results By Charles E. Heywood

\section{U.S. GEOLOGICAL SURVEY}

Water-Resources Investigations Report 00-4291

Prepared in cooperation with the

City of Albuquerque Public Works Department, Water Resources Management 


\title{
U.S. DEPARTMENT OF THE INTERIOR \\ GALE A. NORTON, Secretary
}

\author{
U.S. GEOLOGICAL SURVEY
}

Charles G. Groat, Director

The use of firm, trade, and brand names in this report is for identification purposes only and does not constitute endorsement by the U.S. Geological Survey.

For additional information write to:

\section{District Chief}

U.S. Geological Survey

Water Resources Division

5338 Montgomery Blvd. NE, Suite 400

Albuquerque, NM 87109-1311
Copies of this report can be purchased from:

U.S. Geological Survey Information Services

Box 25286

Denver, CO 80225-0286

Information regarding research and data-collection programs of the U.S. Geological Survey is available on the Internet via the World Wide Web. You may connect to the home page for the New Mexico District Office using the URL http://nm.water.usgs.gov. 


\section{CONTENTS}

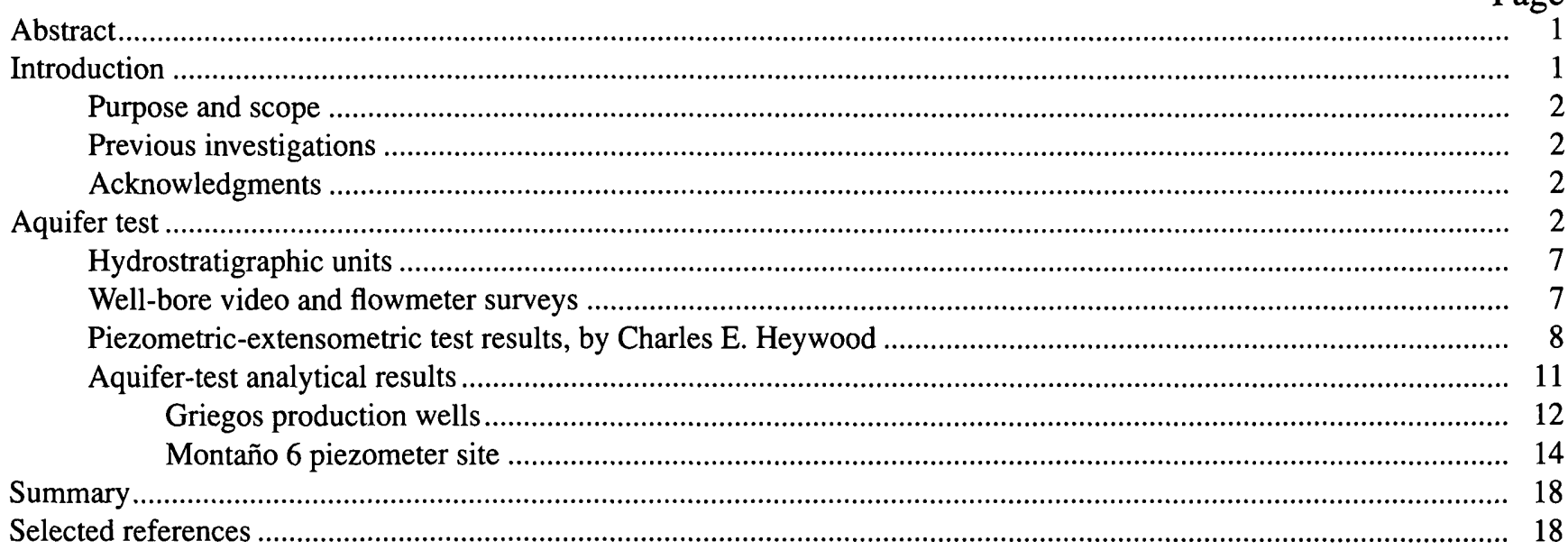

\section{PLATE [inside back pocket]}

Plate 1. Lithologic and geophysical logs and completion diagrams of the City of Albuquerque production wells and Montaño piezometer sites instrumented for an aquifer test near the Rio Grande, Albuquerque, New Mexico

\section{FIGURES}

1. Map showing location of the City of Albuquerque production wells, Montaño piezometer sites, and U.S. Geological Survey streamflow-gaging stations near the Griegos well field.

2. Map showing location of the Griegos production wells and Montaño piezometer sites in the vicinity of the Griegos well field

3-6. Diagrams showing:

3. Fullness of reservoir (A), well discharge (B), and depth to water (C) for the pumping period of the Griegos aquifer test.

4. Montaño 6 and 2 piezometer site installation, lithologic and geophysical logs, and extensometer installation for the Montaño 6 piezometer site

5. Pore-pressure change at 561 feet below land surface in relation to aquifer-system strain measured at the Montaño 6 piezometer site during the pumping and recovery periods of the Griegos aquifer test.

6. Pore-pressure change at 561 feet below land surface in relation to aquifer-system strain measured at the Montaño 6 piezometer site with additional 60 days of post-test pumping data

7. Hydrographs from the Montaño 2 and 3 piezometer sites

8-10. Semi-log plot and computer-assisted type-curve matching from the:

8. Griegos 1 production well

9. Griegos 4 production well

10. Montaño 6 piezometer site, 558 - to 563 -foot completion

\section{TABLES}

1. Completion data and type of instrumentation for observation wells and piezometer sites instrumented for the aquifer test at the Griegos well field.

2. Summary of estimated aquifer properties from the Griegos aquifer test...... 
CONVERSION FACTORS AND VERTICAL DATUM

\begin{tabular}{rll}
\hline Multiply & By & To obtain \\
inch & 25.40 & millimeter \\
foot & 0.3048 & meter \\
mile & 1.609 & kilometer \\
gallon & 0.0 .003785 & cubic meter \\
gallon per minute & 0.06309 & liter per second \\
foot squared per day & 0.0929 & meter squared per day \\
pound per square foot & 47.88 & pascal \\
pound per cubic foot & 16.02 & kilogram per cubic meter \\
\hline
\end{tabular}

Sea level: In this report, "sea level" refers to the National Geodetic Vertical Datum of 1929-a geodetic datum derived from a general adjustment of the first-order level nets of the United States and Canada, formerly called Sea Level Datum of 1929. 


\section{Analytical Results of a Long-Term Aquifer Test Conducted near the Rio Grande, Albuquerque, New Mexico}

By Condé R. Thorn

With a Section on

Piezometric-Extensometric Test Results

By Charles E. Heywood

\section{ABSTRACT}

The City of Albuquerque, New Mexico, is interested in gaining a better understanding, both quantitative and qualitative, of the aquifer system in and around Albuquerque. Currently (2000), the City of Albuquerque and surrounding municipalities are completely dependent on ground-water reserves for their municipal water supply. This report presents the results of a longterm aquifer test conducted near the Rio Grande in Albuquerque.

The long-term aquifer test was conducted during the winter of 1994-95. The City of Albuquerque Griegos 1 water production well was pumped continuously for 54 days at an average pumping rate of 2,331 gallons per minute. During the 54-day pumping and a 30 -day recovery period, water levels were recorded in a monitoring network that consisted of 3 production wells and 19 piezometers located at nine sites. These wells and piezometers were screened in river alluvium and (or) the upper and middle parts of the Santa Fe Group aquifer system. In addition to the measurement of water levels, aquifer-system compaction was monitored during the aquifer test by an extensometer. Well-bore video and flowmeter surveys were conducted in the Griegos 1 water production well at the end of the recovery period to identify the location of primary waterproducing zones along the screened interval.

Analytical results from the aquifer test presented in this report are based on the methods used to analyze a leaky confined aquifer system and were performed using the computer software package AQTESOLV. Estimated transmissivities for the Griegos 1 and 4 water production wells ranged from 10,570 to 24,810 feet squared per day; the storage coefficient for the Griegos 4 well was 0.0025 . A transmissivity of 13,540 feet squared per day and a storage coefficient of 0.0011 were estimated from the data collected from a piezometer completed in the production interval of the Griegos 1 well.

\section{INTRODUCTION}

The City of Albuquerque, New Mexico (City), is interested in gaining a better understanding, both quantitative and qualitative, of the aquifer system in and around Albuquerque. Currently (2000), the City and surrounding municipalities are completely dependent on ground-water reserves for their municipal water supply. The understanding of the aquifer system within the Albuquerque area has been refined within the last several years. Hawley and Haase (1992), Hawley (1996), and Connell and others (1998) presented updated refinements of the hydrogeologic framework of the Albuquerque Basin with emphasis on the Albuquerque area. Thorn and others (1993) presented information suggesting that the most productive parts of the aquifer system were less extensive and thinner than previously assumed. Kernodle and others (1995) simulated the surfacewater/ground-water system and estimated the effect of ground-water withdrawals by the City on the Rio Grande, and discovered that the effect of pumping on the Rio Grande by the City was less than in past predictions. On the basis of these and other investigations, officials from the City decided that the effects of long-term pumping from a City water production well on the surrounding aquifer system and on the Rio Grande needed to be further defined. In July 
1994, the U.S. Geological Survey (USGS), in

cooperation with the City of Albuquerque, designed a long-term aquifer test to further define aquifer properties near the Rio Grande in the area of the Griegos well field in Albuquerque.

\section{Purpose and Scope}

This report presents the analytical results of a long-term aquifer test conducted to define hydraulic properties of the Santa Fe Group aquifer system in the vicinity of the Griegos well field in Albuquerque, New Mexico. McAda (2001), in a companion report, described a finite-difference ground-water flow-model analysis of this same aquifer test. The Griegos well field was chosen as the aquifer-test site because its location allowed for a minimum number of other City wells to be shut down during the test and because a monitoring-well network had previously been installed in the area. The aquifer test was designed for a longterm, sustained duration of pumping that would create drawdowns expected to exceed the normal drawdown caused by the typical pumping schedules that have been used in the area since the mid-1950's, when the Griegos and nearby Duranes well fields began production.

\section{Previous Investigations}

The most recent (2000) understanding of the hydrogeologic framework of the Albuquerque Basin, with emphasis on the Albuquerque area, is reported in Hawley and Haase (1992), Hawley (1996), and Connell and others (1998). Thorn and others (1993) updated understanding of the geohydrologic and hydrologic conditions of the Albuquerque Basin. Simulation of ground-water flow in the Albuquerque Basin was reported in Kernodle and others (1995).

Anderholm and Bullard (1987) presented lithologic and geophysical logs and completion diagrams for most of the piezometer sites used to measure water levels during the aquifer test. Short-term aquifer tests were previously conducted on Griegos 1, 3, and 4 water production wells during February 1987 and described by Groundwater Management, Inc. (1988).

\section{Acknowledgments}

The author thanks the personnel of the City of Albuquerque Public Works Department, Water Resources Management, who arranged to shut down well production for the Griegos and Duranes well fields for 6 months. Without this shutdown, the aquifer test would not have been possible. The author also appreciates all those involved at the City Public Works Department for allowing the drilling of a borehole extensometer and installation of a piezometer nest at the Montaño 6 piezometer site. A special thanks is extended to Dr. John Hawley (private consultant, Geomatters) for logging and describing the drill cuttings from the Montaño 6 piezometer site.

\section{AQUIFER TEST}

A long-term aquifer test (test) was conducted near the Rio Grande in the winter of 1994-95 to define the hydraulic properties of the Santa Fe Group aquifer system in the vicinity of the City Griegos well field (fig. 1). The test was conducted during the winter months for several reasons. (1) Nearby City production wells in the Duranes and Griegos well fields (fig. 1) could be shut down, thereby eliminating drawdown effects attributed to them. (2) City water demand is lowest during the winter months, and alternative watersupply scheduling could be arranged to compensate for the temporary closure of the Duranes and Griegos well fields. (3) Irrigation diversions from the Rio Grande are stopped by November 1 of each year, drying up the canals, drains, laterals, and ditches, so flow in the Albuquerque Riverside Drain returns to base-flow conditions. Consequently, the potential effects of surface-water recharge from the nearby distribution system of canals, drains, laterals, and ditches (fig. 2) were minimized. (4) Evapotranspiration effects were minimized because of the lack of transpiring vegetation. (5) Variation of flow in the Rio Grande was minimal because of the steady release from a reservoir upstream from Albuquerque and the lack of runoff from thunderstorms that are common in the spring and summer seasons. A single pumped well (Griegos 1) was used for the aquifer test, and the effects of pumping on water levels were monitored in 3 production wells (including Griegos 1) and 19 piezometers located at nine different sites (fig. 2). Completion data for the wells and piezometers are listed in table 1. 


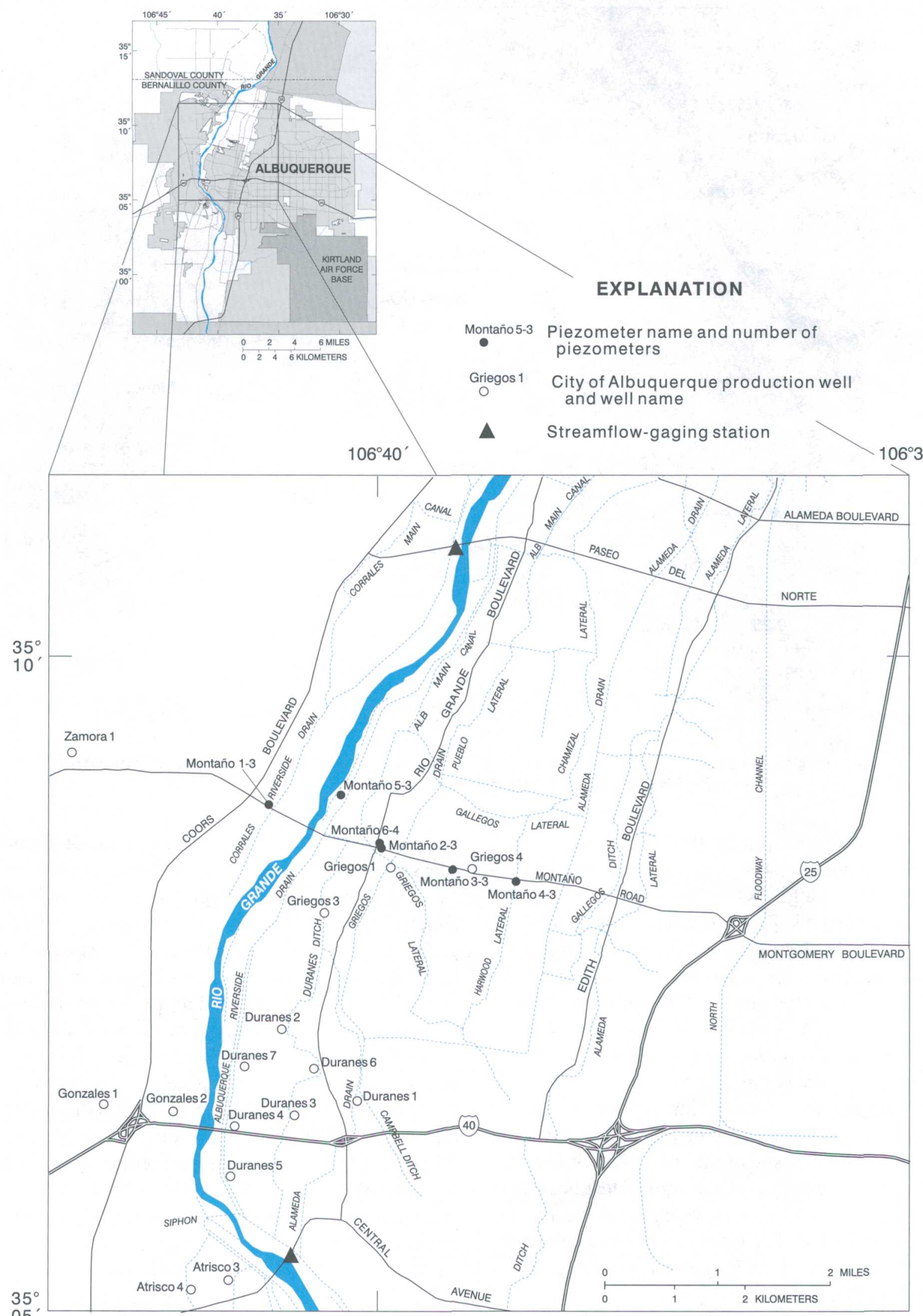

Figure 1. Location of the City of Albuquerque production wells, Montaño piezometer sites, and U.S. Geological Survey streamflow-gaging stations near the Griegos well field. 


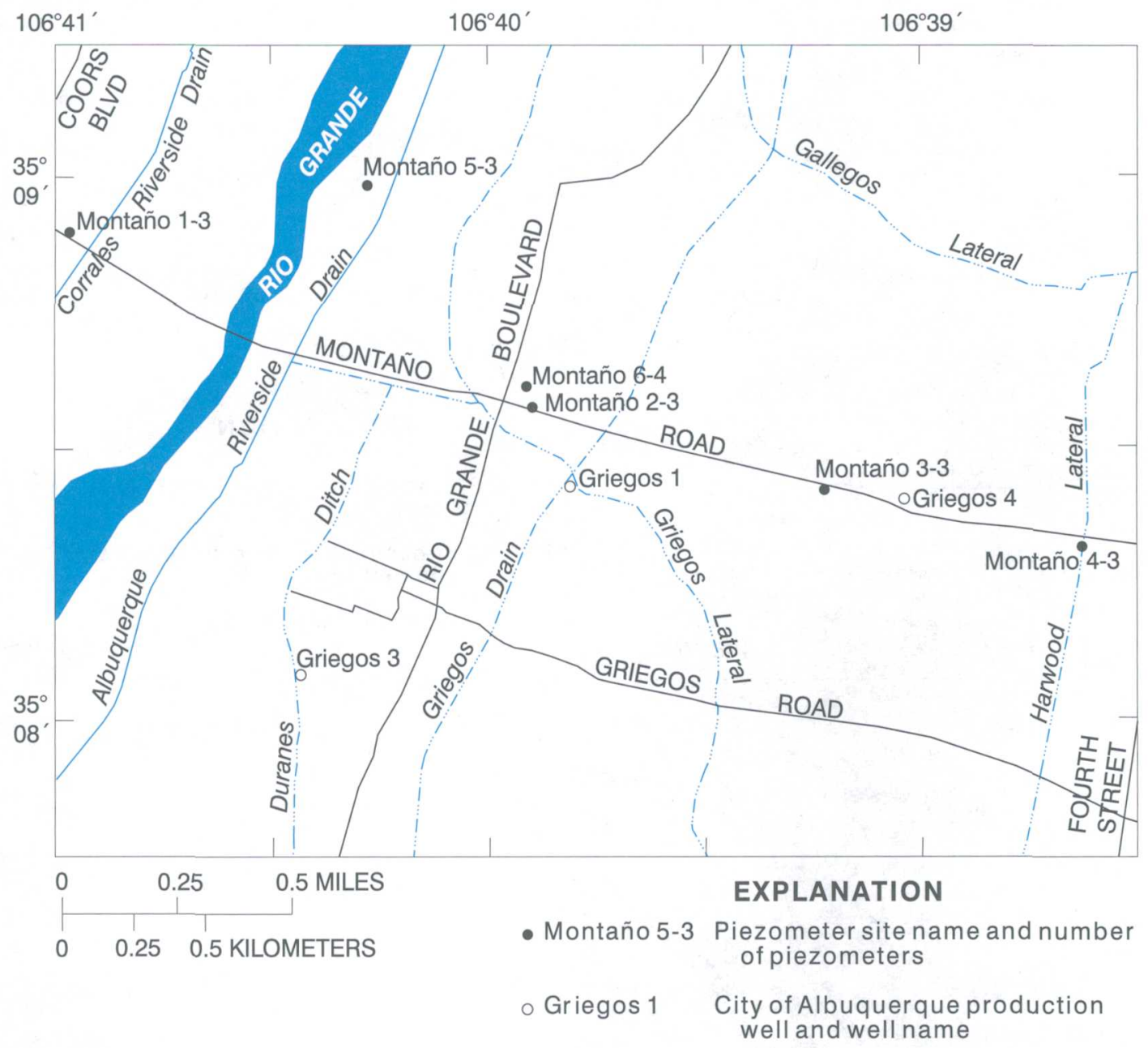

Figure 2. Location of the Griegos production wells and Montaño piezometer sites in the vicinity of the Griegos well field.

Production from wells in the Duranes and Griegos well fields (fig. 1) was stopped beginning October 1, 1994, to allow water levels in the vicinity to recover to static levels. Pre-test water levels were measured using depth-to-water recording equipment at the Griegos 1, 3, and 4 production wells and the Montaño 1-5 piezometer sites for 2 months prior to the aquifer test (fig. 2). A borehole extensometer and a quadruple-completed piezometer (Montaño 6 piezometer site) were completed during November 1994. Instrumentation for recording depth-to-water measurements was installed in the piezometers at the Montaño 6 piezometer site during early December 1994. The pumping period of the aquifer test began January 4, 1995, at 0933 hours, when the pump for Griegos 1 was started. The Griegos 1 well maintained an average discharge of 2,331 gallons per minute for about 54 days (fig. 3 ).

Water discharged from Griegos 1 was piped into an onsite reservoir located about 80 feet from the well. When the reservoir was full, the water was released into the City's water-distribution system. On January 5 (the second day of the test), an unplanned power outage caused the pump in the Griegos 1 well to shut down for about 27 minutes; the results of this pump shutdown period are shown in figure 3B-C. Also displayed in figure 3 is the variation in depth to water in Griegos 1 , about 3 feet, which is related to the percent fullness of the onsite reservoir, which in turn created a diurnal fluctuation in the pump's discharge rate. The periodicity displayed on the graphs in figure 3 is related to the change in pump efficiency (pump discharge) as the water level in the onsite reservoir rose (percent fullness). The entry pipe into the onsite reservoir from the Griegos 1 pump is about two-thirds up the side of the reservoir tank. As the water level in the reservoir rose above the entry pipe, the efficiency of the pump in Griegos 1 decreased, resulting in a decrease in the pump discharge rate. The diurnal fluctuation of reservoir fullness, well discharge, and depth to water in Griegos 1 was evident throughout the entire pumping interval of the aquifer test (fig. 3). 


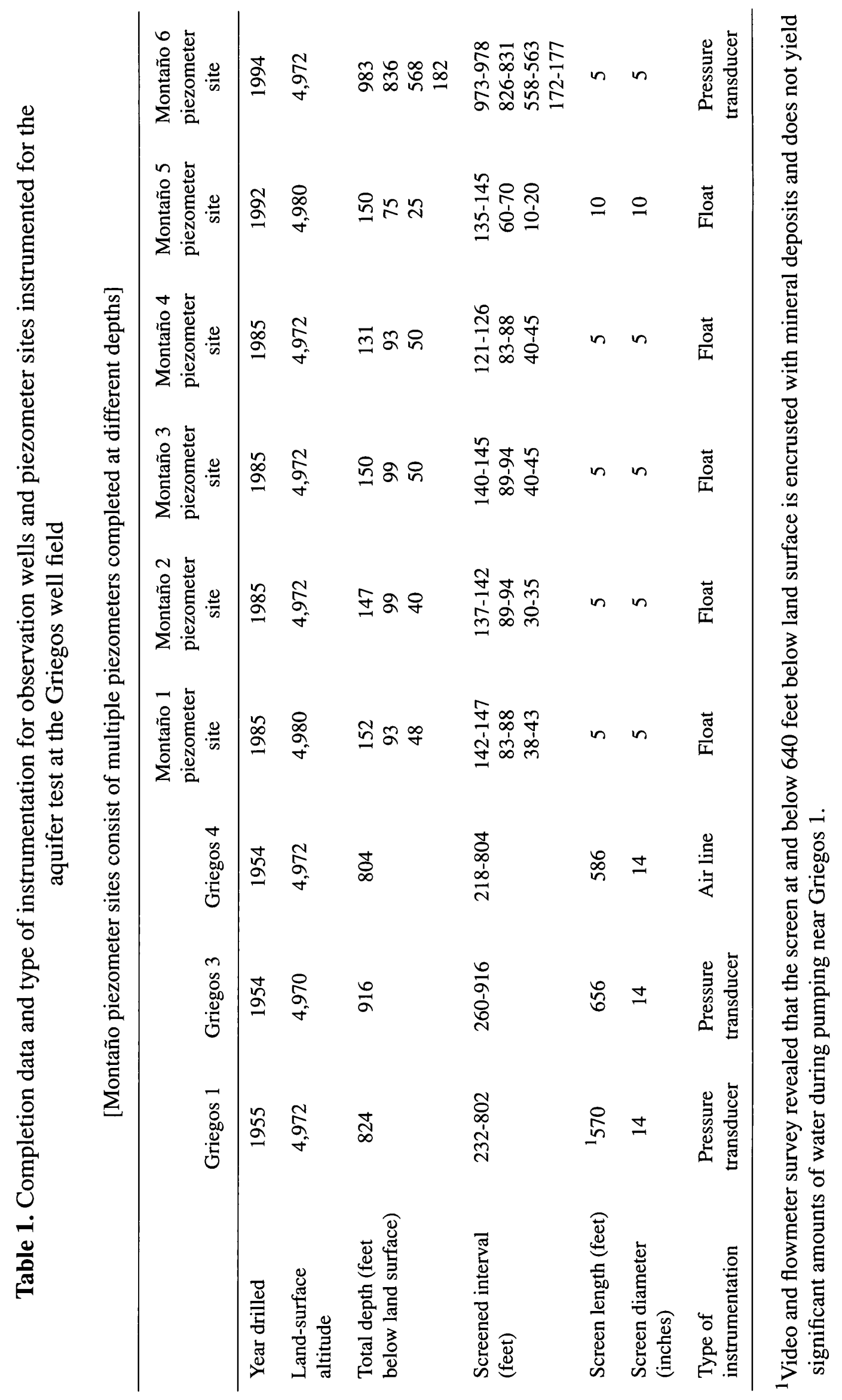




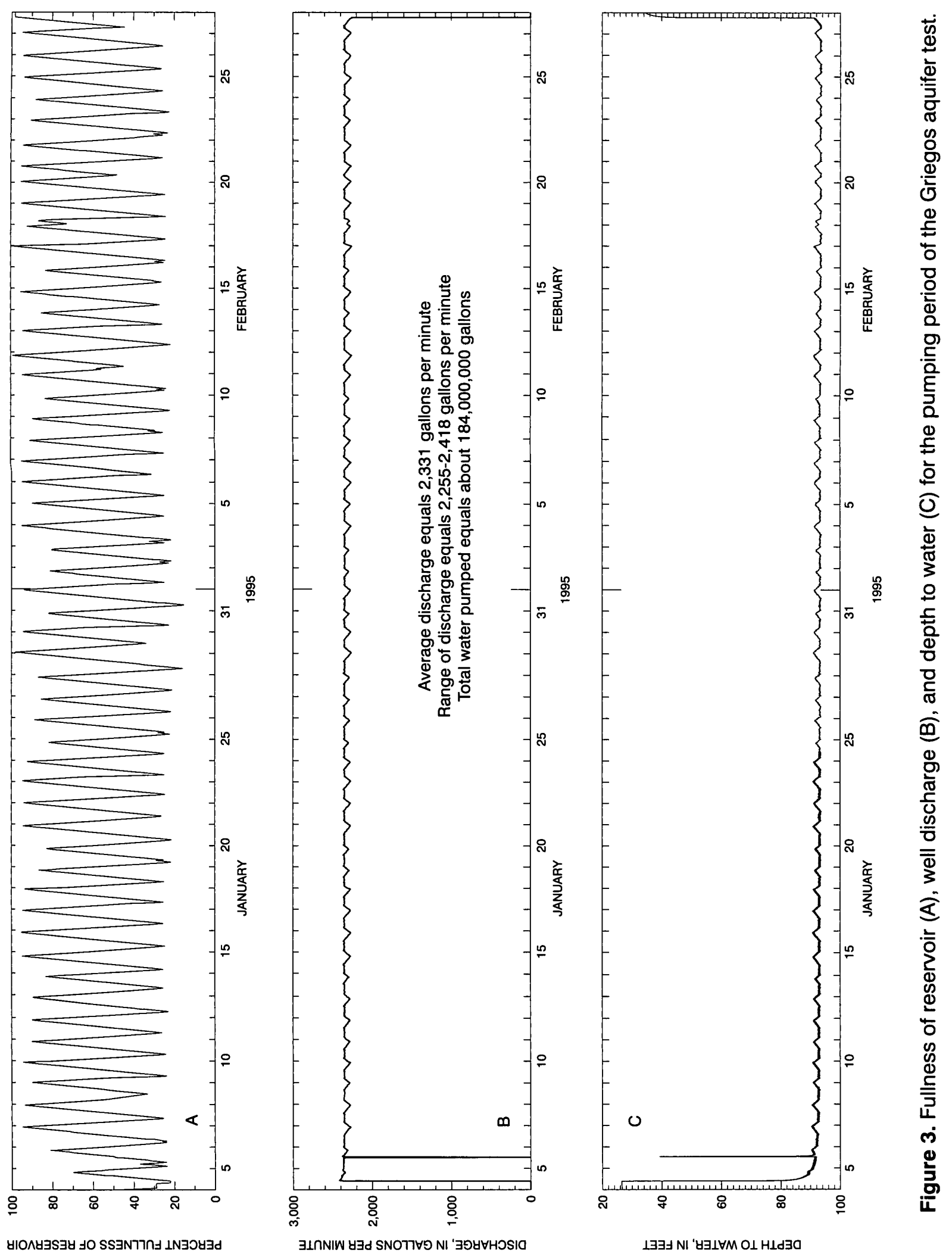


Surface-water discharge was measured during the aquifer test at the two closest USGS streamflowgaging stations on the Rio Grande (fig. 1); records obtained from the two stations were rated as fair (about 95 percent of the daily discharges are within 15 percent of the true value) (Ortiz and Lange, 1996, p. 10). Two areas on the Albuquerque Riverside Drain, one upstream and one downstream from the aquifer-test area, were established for weekly surface-water discharge measurements that began 1 month before the start of pumping and ended at the end of the pumping period. The surface-water discharge measurements obtained on the Albuquerque Riverside Drain were rated good (about 95 percent of the daily discharges are within 5 percent of the true value) (U.S. Geological Survey, 1982, p. 181). As indicated by the discharge measurements, pumping Griegos 1 for the aquifer test had no noticeable effect on discharge of the

Albuquerque Riverside Drain or the Rio Grande during the test. Therefore, no attempt is made in this report to estimate surface-water recharge from the Albuquerque Riverside Drain or the Rio Grande during the Griegos aquifer test. For a discussion on estimated effects on the Rio Grande and the Albuquerque Riverside Drain during the Griegos aquifer test, the reader is referred to McAda (2001).

The pumping period of the aquifer test was stopped on February 27, 1995, at about 1831 hours. Water-level recovery was monitored in the network for about 30 days. The pump for Griegos 1 was inadvertently started and run for about 2 hours on the second day of recovery. After review of the recovery data, the amount of recovery in water levels was determined to be equal to the amount of drawdown that occurred when compared for equal time periods. For example, the amount of recovery 2 weeks after the pump was shut off was equal to the amount of drawdown that occurred the first 2 weeks of pumping. This equivalency of recovery and drawdown was confirmed for different time periods and for different piezometer sites. Therefore, recovery data are not analyzed in this report.

\section{Hydrostratigraphic Units}

The piezometers and wells in the aquifer-test area penetrate three hydrostratigraphic units: river alluvium (RA) of late Pleistocene to Holocene age and the upper (USF) and middle (MSF) parts of the Santa Fe Group of late Miocene to Pliocene age (pl. 1). These units compose the Santa Fe Group aquifer system in the Albuquerque area. The upper unit, the river alluvium, consists of sand, gravel, and boulders that were deposited in a channel-flood-plain setting (Hawley, 1996). The middle unit, the upper part of the Santa Fe Group, consists predominantly of gravelly sand, sand, and clay that are fine- to coarse-grained fluvial deposits of the ancestral Rio Grande (Hawley, 1996). The lowermost unit, the middle part of the Santa Fe Group, consists of clay, sand, and sandy clay that were deposited in alluvial, eolian, and playa lake depositional settings (Hawley, 1996). Hawley and Haase (1992) and Hawley (1996) provided detailed descriptions of the hydrostratigraphic units in the Griegos well field area.

\section{Well-Bore Video and Flowmeter Surveys}

The USGS conducted well-bore video and flowmeter surveys of the screened interval of the Griegos 1 well just after the 30-day recovery period. These surveys helped define the position and extent of the more productive zones contributing water to the well bore under pumping conditions. The video survey along the well screen showed signs of encrustation by mineralization at and below about 640 feet below land surface (pl. 1). This mineral encrustation restricts the contribution of water from the aquifer to the well bore. The video survey went to a total depth of 700 feet below land surface, where visibility decreased to zero because of murky water in the well bore; the well-bore flowmeter survey began 700 feet below land surface.

A flowmeter is a device that measures the vertical flow of water in a well bore (Molz and others, 1989; Rehfeldt and others, 1989; and Hanson and Nishikawa, 1996). The wellbore was logged with a Well Reconnaissance four-bladed impeller flowmeter that transmits pulses indicating the number of revolutions of the impellers per unit time. Vertical movement of water past the flowmeter impellers causes them to rotate about their axis at a speed proportional to the water velocity. A three-legged caliper tool was connected below the flowmeter to centralize the flowmeter in the well bore. In line and below the flowmeter was a 5-foot-long, solid steel cylinder designed to provide additional mass (sinker bar). The total length of this in-line combination of caliper tool, flowmeter, and sinker bar (collectively referred to as the tool) was about 15 feet. 
The tool was lowered to 700 feet below land surface, at which point the caliper arms were opened. When the caliper arms were fully extended, the tool was raised to the top of the screened interval at a constant tool speed of about 10 feet per minute (continuous logging), thus creating a log of the cumulative upward well-bore flow (see pl. 1). A submersible pump set within the blank casing above the screened interval allowed for uniform pumping conditions during the flowmeter survey. After evaluation of the cumulative upward well-bore flow log (flow $\log$ ), stationary flowmeter measurements were made for selected zones to verify measurements recorded during continuous logging.

The flow log, lithologic log, and well completion for Griegos 1 are displayed on plate 1. Significant flow to the well bore began at a depth about 640 feet below land surface, below which the screen is plugged because of mineralization. Aquifer material adjacent to the unplugged part of the screened interval (232-640 feet) contributed water to the well bore in differing volumes, as indicated by the change in slope of the flow $\log$ displayed on plate 1 . As the log trends to the right, away from the vertical position, the rate of flow of water from the aquifer to the well bore increases. The rates of flow from the aquifer, as indicated by the log, are greatest at depths of about $360-380$ and $540-560$ feet below land surface (pl. 1). Both of these highly productive zones correspond with aquifer material representative of high permeability, as shown on the adjacent lithologic log from Griegos 1 (pl. 1). Two zones that contribute the least amount of water to the well bore are at about 425-525 and 600-630 feet below land surface. The 425- to 525-foot zone corresponds to sandy clay as shown on the lithologic log from Griegos 1 (pl. 1). At about 420 feet below land surface, the log displays a sharp spike to the left, indicating a sudden decrease of flow to the well bore. This spike is most likely due to the impellers on the flowmeter becoming temporarily impaired after being hit with a piece of suspended debris in the well bore.

\section{Piezometric-Extensometric Test Results}

\section{By Charles E. Heywood}

An extensometer was installed (fig. 4) about 1,240 feet from the pumped well (Griegos 1 ) to monitor aquifer-system compaction resulting from groundwater withdrawal. The 1,033-foot-deep counterweighted borehole pipe extensometer was designed along guidelines described by Riley (1986) to achieve high strain sensitivity. A transducer was installed that detects vertical displacements with a resolution of several microns, corresponding to a vertical strain sensitivity of $10^{-8}$. A nest of four piezometers (the Montaño 6 piezometer site) was installed about 20 feet from the extensometer, and each piezometer was equipped with a transducer capable of detecting about 0.08 inch of water-level change.

Figure 5 is a graph of aquifer pore-pressure change, measured at the Montaño 6 piezometer site at a depth 561 feet below land surface, in relation to vertical strain, measured with the extensometer, for the pumping and recovery periods of the aquifer test. The 27-minute-long pump failure on day 2 of the aquifer test caused measurable elastic recovery of the aquifer system at the extensometer, resulting in a small loop in this graph (fig. 5). An analogous effect was seen in the test recovery period on day 55 when the pumped well was inadvertently turned back on for about 2 hours (fig. 5). Piezometer hydrographs "flattened" approximately 1 week into the drawdown and recovery periods of the test, suggesting recharge to permeable aquifer sands from the nearby Rio Grande or from the water table. In figure 5, the lower slope from day 7 to day 54 probably represents compaction of interbedded, lower permeability sediments as they slowly drained excess pore pressure to the surrounding aquifer.

Figure 6 displays the controlled-test data of figure 5 with an additional 60 days of post-test pumping data superimposed. During the 60 days following the test, normal pumping by wells near the extensometer resulted in drawdowns of various magnitudes with approximately daily periodicity. The stress-strain plot during this period shifts to the right of the plot for the controlled test, indicating inelastic compaction of clay interbeds during the aquifer test. Since the late 1950's, production wells near the extensometer have generated approximately diurnal drawdown of a magnitude similar to that generated during the aquifer test; however, the aquifer system probably never experienced the magnitude of constant drawdown for a period as long as the 54-day aquifer test. Effective stress magnitudes in the middle of thicker, low-permeability clay interbeds may, therefore, have exceeded preconsolidation levels during the test, resulting in inelastic compaction totaling about 0.02 inch over the 1,033-foot interval measured by the extensometer. Presumably, this compaction occurred in the thicker clay interbed fraction of this interval. 


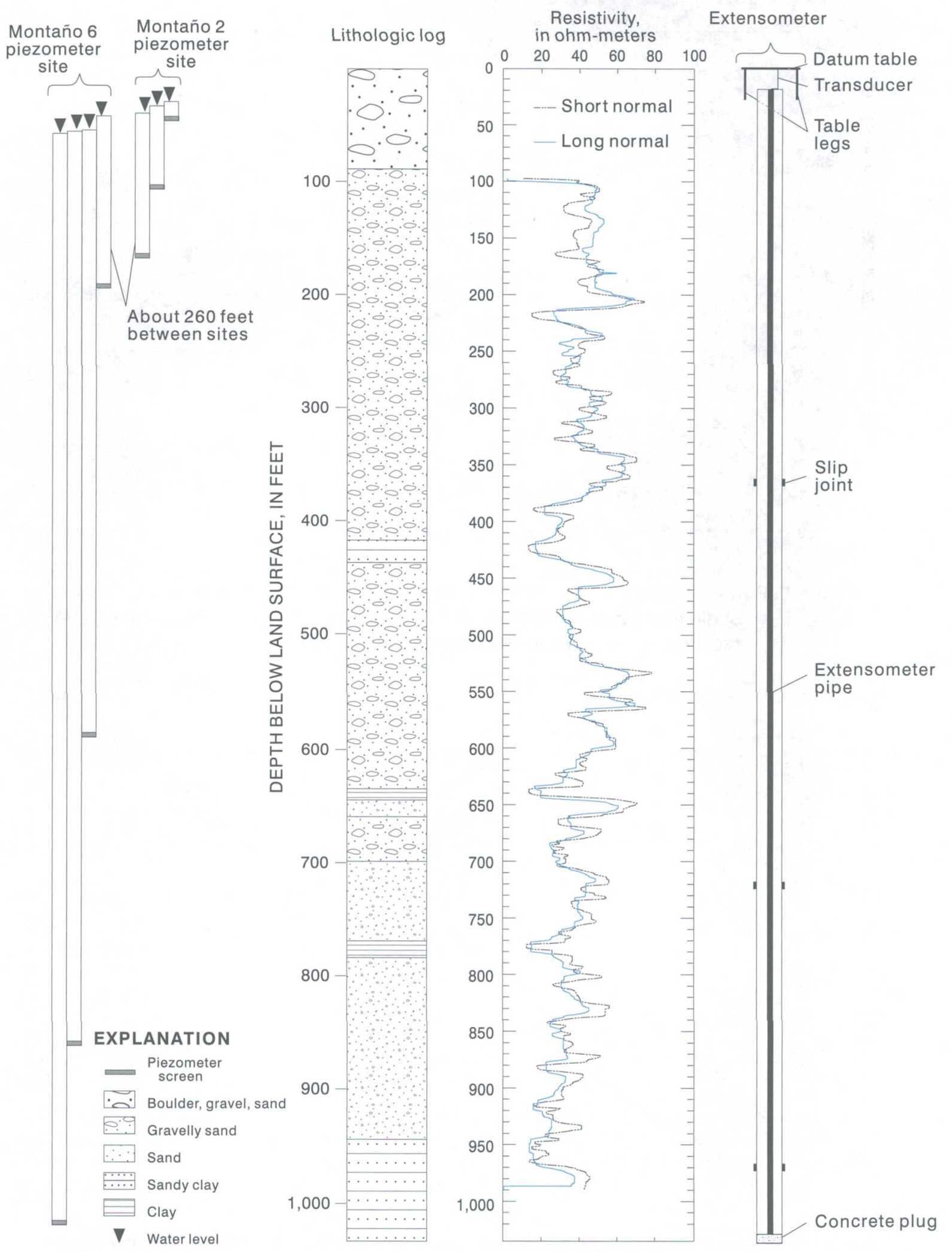

Figure 4. Montaño 6 and 2 piezometer site installation, lithologic and geophysical logs, and extensometer installation for the Montaño 6 piezometer site (modified from Heywood, 1998). 


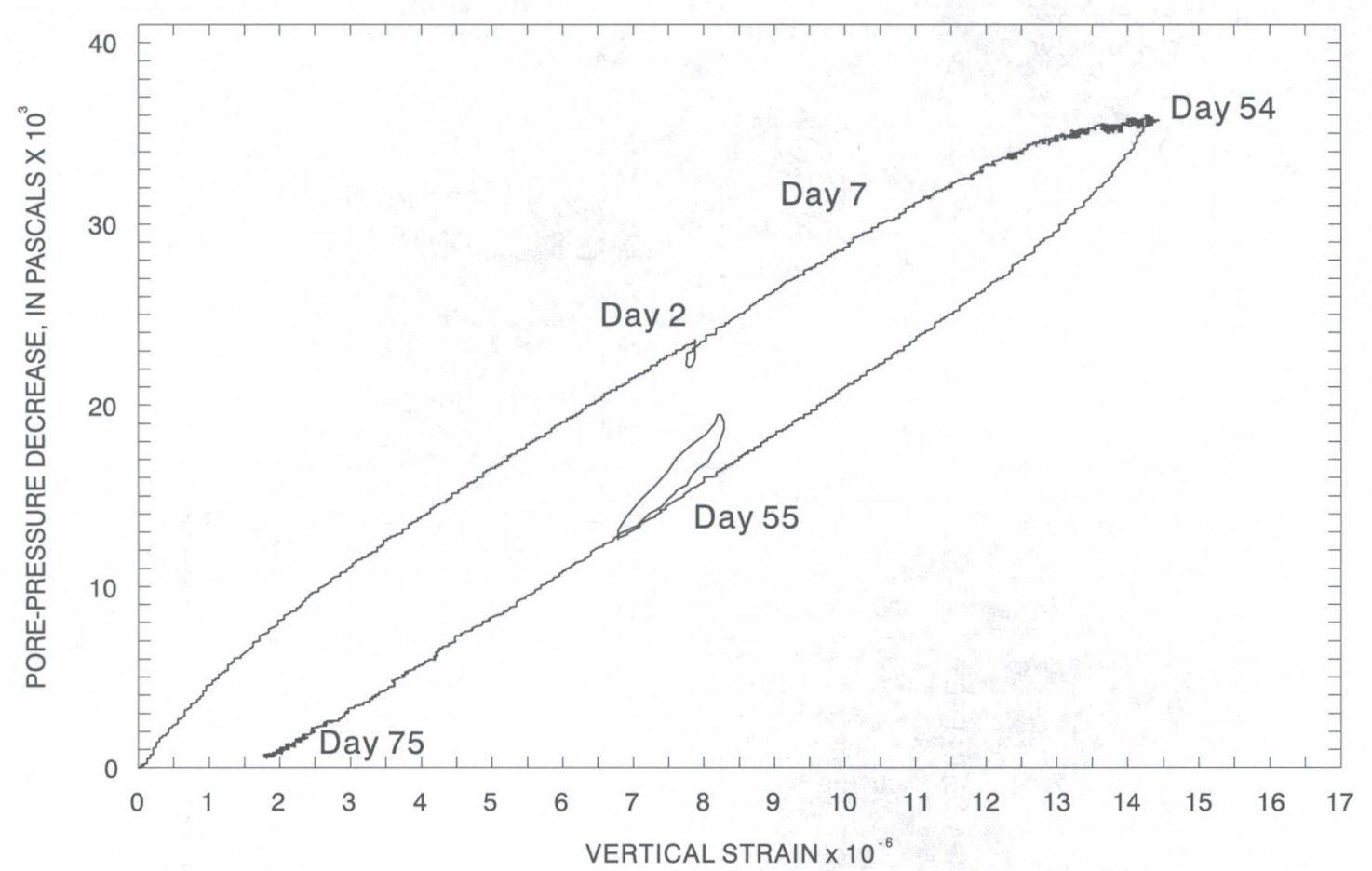

Figure 5. Pore-pressure change at 561 feet below land surface in relation to aquifer-system strain measured at the Montaño 6 piezometer site during the pumping and recovery periods of the Griegos aquifer test.

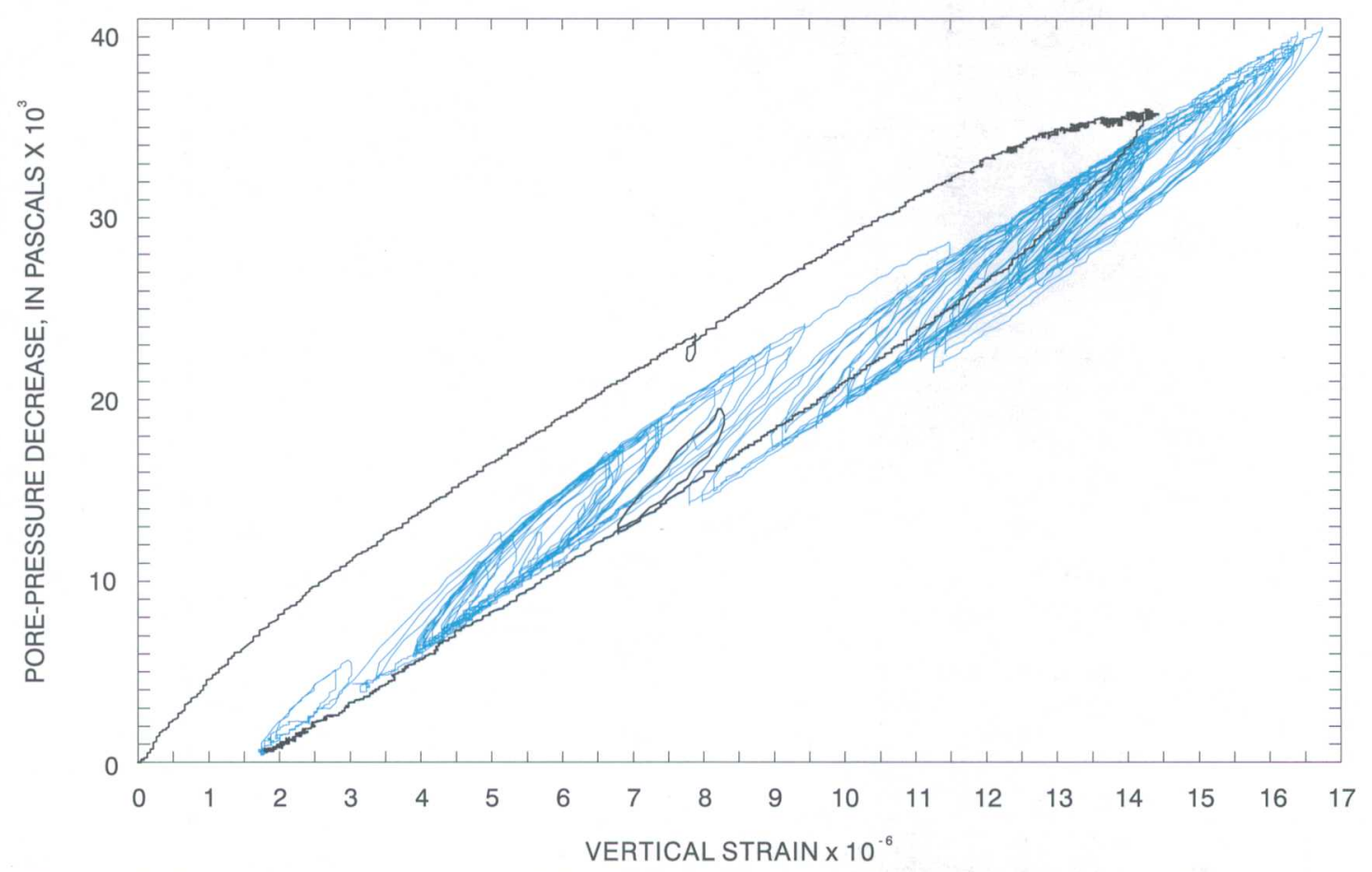

Figure 6. Pore-pressure change at 561 feet below land surface in relation to aquifer-system strain measured at the Montaño 6 piezometer site with additional 60 days of post-test pumping data. Data collected during the pumping and recovery periods (black line) of the Griegos aquifer test and subsequent period of normal pumping (blue line) by nearby City of Albuquerque production wells. 
The shallowest piezometer near the extensometer site is screened across the water table. During the aquifer test, the water-table altitude recorded in the piezometer declined less than 1 foot. By assuming a specific yield of 0.2 , the resulting decrease in geostatic stress of the underlying sediments was less than 0.09 pound per square inch $\left(6 \times 10^{2}\right.$ pascals $\left.(\mathrm{Pa})\right)$. Measured pore pressure decreased by 5.2 pounds per square inch $\left(3.6 \times 10^{4} \mathrm{~Pa}\right)$ in the piezometer completed from 558 to 563 feet below land surface and by somewhat less in the piezometers screened at the other depths. For sediments in the production interval of the aquifer (about 232 to 802 feet below land surface), the magnitude of decreased effective stress resulting from water-table lowering was, therefore, less than 2 percent of the increased effective stress resulting from decreased pore pressure. Because the effect of watertable lowering on effective stress at depth was relatively minor during the pumping period of the test, the water table was assumed to be static so that a unit decrease in measured pore pressure corresponded to a unit increase in effective stress. Because the extensometer measures strain integrated over a 1,033foot interval, the average compressibility of this interval may be determined by inferring the average change in effective stress from a sampling of porepressure changes in this interval.

Riley (1970) demonstrated the use of similar stress-strain plots for determining elastic and inelastic storage coefficients. The magnitude of the inverse slope of this stress-strain plot is a measure of the average aquifer-matrix compressibility over the interval spanned by the extensometer, assuming that the change in pore pressure is uniform over that interval. The distribution of aquifer-system pore-pressure change was sampled with piezometers at seven depth intervals (the Montaño 2 and 6 piezometer sites). Sample hydrographs were used in conjunction with the vertical-permeability distribution inferred from the borehole-resistivity log to estimate the change in vertical pore-pressure distribution during the aquifer test. The average pore-pressure change over the sampled aquifer-system interval was approximated by the average drawdown recorded in the four deepest piezometers (Montaño 6 piezometer site). For the aquifer-system interval spanned by the extensometer, the resulting estimated matrix compressibility $(\alpha)$ is $2.4 \times 10^{-8}$ foot squared per pound $\left(5 \times 10^{-10} \mathrm{~Pa}^{-1}\right)$, the average matrix porosity (n) is 0.3 , and the water compressibility $(\beta)$ is $2.1 \times 10^{-8}$ foot squared per pound $\left(4.4 \times 10^{-10} \mathrm{~Pa}^{-1}\right)$; the corresponding specific storage is given by $S_{s}=\rho g(\alpha+n \beta)$ is $2 \times 10^{-6}$ foot $^{-1}\left(6 \times 10^{-6}\right.$ meter $\left.^{-1}\right)$, where $\rho g=62.46$ pounds per cubic foot $\left(9,800\right.$ kilograms $\left./ \mathrm{m}^{2} \mathrm{~s}^{2}\right)$ is the weight density of water.

\section{Aquifer-Test Analytical Results}

The 22 wells and piezometers instrumented for collection of water-level (hydraulic head) data during the aquifer test were located at nine different sites (pl. 1). Three of the monitoring sites were City water production wells (Griegos 1, 3, and 4), and the other six sites consisted of a total of 19 piezometers (Montaño 16 piezometer sites). The screened intervals of the production wells extend over hundreds of feet; for this report, the production interval is defined by the length of well screen open to the aquifer in the Griegos 1 well, which is from 232 to 640 feet below land surface (pl. $1)$. In contrast, the screened intervals of the piezometers are 5 or 10 feet in length (table 1). The piezometers at the Montaño 1-5 sites are completed above the production interval of the Griegos 1 well. At the Montaño 6 piezometer site, one piezometer is completed at a depth of 172-177 feet and is above the production interval, one is completed at a depth of 558563 feet and is within the production interval, and two are completed at depths of 826-831 feet and 973-978 feet and are below the production interval (table 1; pl. 1).

Hydraulic-head data from all monitoring sites were measured at small time intervals, less than 1 minute during the initial period of pumping, and gradually increased during the pumping period of the aquifer test. All hydraulic-head data were measured at 5 -minute intervals 48 hours after the test started.

Within the first week after the start of the test, the 5minute measurement interval was increased to 15 minutes. The 15-minute measurement interval was maintained until just before the pump was shut off; the measurement interval was then reduced to less than 1 minute to capture recovery of water levels. Within 48 hours after recovery began, the measurement interval was increased to 15 minutes. The 15 -minute measurement interval was maintained for the remainder of the recovery period.

Hydraulic-head data were corrected for changes in the atmospheric pressure during the aquifer test. Atmospheric pressure was recorded at Griegos 1, and barometric efficiencies were calculated for all piezometers and wells as outlined in Walton (1962). Hydraulic-head data from the Montaño 5 piezometer 
site (135- to 145 -foot completion) were corrected for the effects of changing stage of the Rio Grande, and a river efficiency calculated by the Walton (1962) method was applied to the data. Hydrographs and timedrawdown (semi-log) plots of corrected hydraulic heads were prepared for all piezometers and wells. Preexisting trends were corrected for the Griegos 4 well, but no further corrections for pre-existing trends were required for any other wells or piezometers.

Seven of the 19 piezometers showed no response to pumping of the Griegos 1 well during the aquifer test: the three piezometers at the Montaño 1 piezometer site, which is located west of the Rio Grande, and the shallow and middle piezometers at the Montaño 4 and 5 piezometer sites (pl. 1). Response to pumping was observed in the three piezometers at the Montaño 2 and 3 piezometer sites (fig. 7) and the deep piezometers at the Montaño 4 and 5 piezometer sites (pl. 1). Timedrawdown data from the responsive piezometers and three wells were evaluated using the analytical methods for which the underlying assumptions most closely matched the geologic and hydrologic conditions and well construction in the test area.

The aquifer system in the test area is a leaky confined system. Fine-grained material (silt, sandy clay, and clay) in the aquifer at all piezometers and wells used for the test are representative of confining beds (pl. 1). The response in the piezometers completed above and below the production interval (the Montaño 2 and 3 piezometer sites and the two deepest completions at the Montaño 6 piezometer site, respectively) indicates that the aquifer system acts as a leaky confined system. By incorporating the available lithologic and response information into the representative conceptual analytical models, the timedrawdown data from the observation wells were evaluated using analytical theories presented by Moench (1985); the time-drawdown data from the pumped well were evaluated using the standard Theis (1935) solution.

The Moench (1985) solution was selected because it combines the leaky aquifer theory and the effects of storage within the confining units of Hantush (1960) with a theory of flow to a large-diameter well (Moench, 1985; Batu, 1998). The diameter of the screened interval of the Griegos 1 well is 14 inches (table 1). The requirements for the conceptual model of the Moench (1985) solution do not allow for wells or piezometers to be analyzed that are completed above or below the aquifer top and bottom. To satisfy the conceptual model of Moench (1985), the aquifer top and bottom are defined in this report as the top and bottom of the screened interval of Griegos 1, the pumped well. In addition, the discrepancy in drawdowns between the Griegos 3 and 4 wells at the end of the pumping period ( 0.95 and 4.20 feet, respectively) is notable. Both wells are about the same distance from Griegos 1 (fig. 1), and some type of hydrologic barrier likely exists between the Griegos 1 and 3 wells. This barrier tends to retard ground-water flow and is suggestive of a fault or a facies change that could exist between the Griegos 1 and 3 wells.

Consequently, pursuing an analytical solution using the results from the Griegos 3 well is not practical.

Analytical results, therefore, will be presented for only those wells and piezometers completed in the production interval--the Griegos 1 and 4 production wells and the piezometer completed at a depth of 558563 feet at the Montaño 6 piezometer site.

The computer software program AQTESOLV was used to analyze the time-drawdown data collected from the Griegos 1 and 4 wells and from the 558- to 563-foot completion at the Montaño 6 piezometer site. The transmissivities and storage coefficients for the Griegos 1 and 4 wells and the one piezometer are listed in table 2. Detailed discussion of observed drawdown and analytical results from the Griegos 1 and 4 wells and the piezometer at the Montaño 6 site follows.

\section{Griegos Production Wells}

Semi-log graphs and computer-assisted typecurve matching solutions for the time-drawdown data collected from the Griegos 1 and 4 production wells are shown in figures 8 and 9. The semi-log plot for the Griegos 1 well (the pumped well) shows four distinct trends that represent changing conditions within the aquifer system as the pumping effects progressed (fig. 8A). The steep trend shown for about the initial 0.4 minute represents the non-equilibrium conditions in the well bore during the initial period of pumping. The trend from about 0.4 to about 80 minutes of pumping represents the migration of the cone of depression out and away from the pumping center. The trend change to a more horizontal line from about 80 to about 1,030 minutes represents a reduction of drawdown that suggests possible recharge from the water table, the Rio Grande, or the Albuquerque Riverside Drain (fig. 2) and (or) the contribution of water from the finer grained (confining) units in the aquifer system (pl. 1). After about 1,030 minutes, the 
MONTAÑO 2

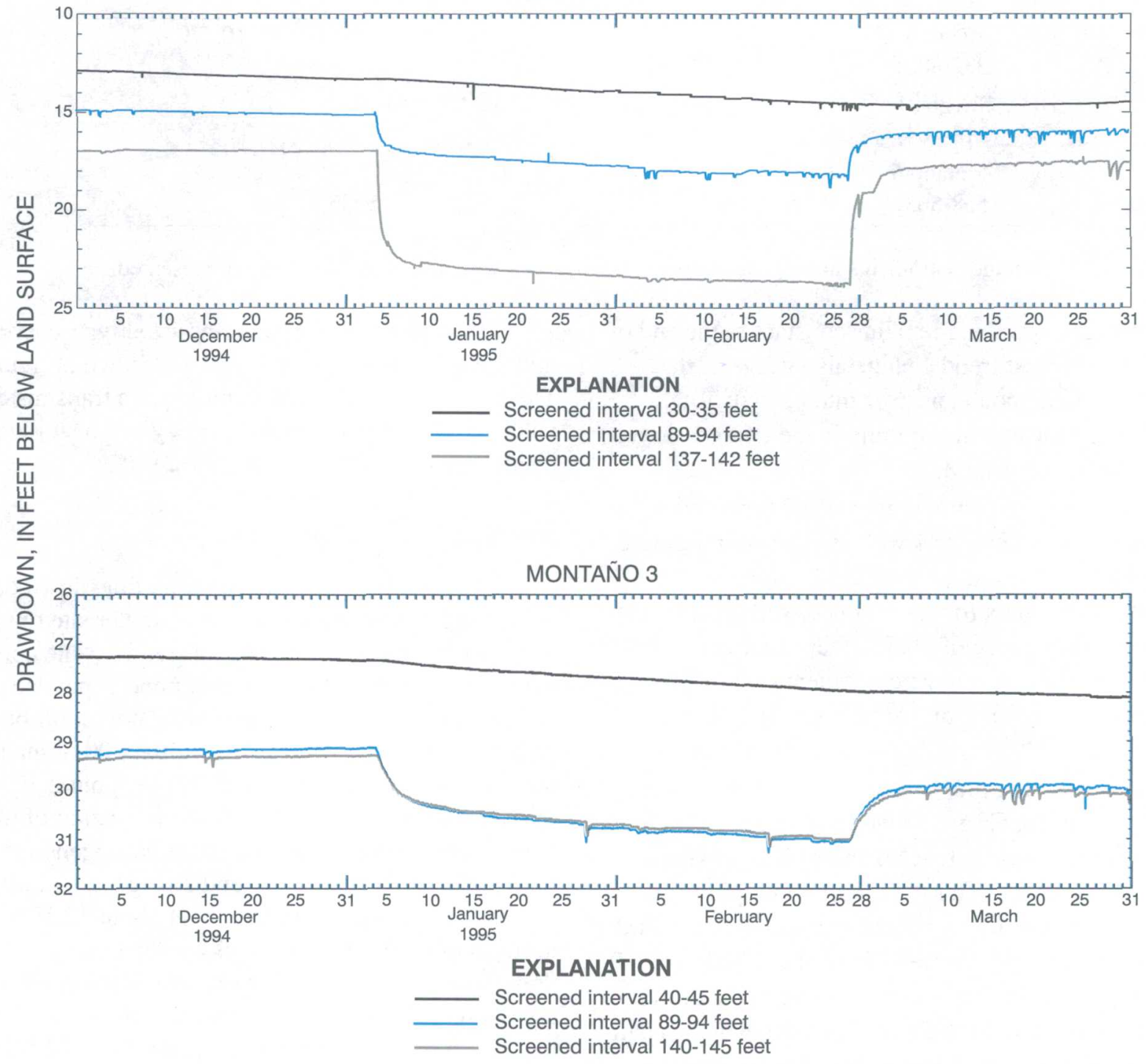

Figure 7. Hydrographs from the Montaño 2 and 3 piezometer sites. 
Table 2. Summary of estimated aquifer properties from the Griegos aquifer test

\begin{tabular}{|c|c|c|c|}
\hline \multirow{2}{*}{$\begin{array}{l}\text { Site name and } \\
\text { screened interval } \\
\text { (feet) }\end{array}$} & \multicolumn{2}{|c|}{ Moench (1985) } & \multirow{2}{*}{$\begin{array}{c}\text { Theis (1935) } \\
\begin{array}{c}\text { Transmissivity (feet } \\
\text { squared per day) }\end{array}\end{array}$} \\
\hline & $\begin{array}{l}\text { Transmissivity (feet } \\
\text { squared per day) }\end{array}$ & Storage coefficient & \\
\hline $\begin{array}{l}\text { Griegos 1 } 1 \\
(232-802)\end{array}$ & & & 10,570 \\
\hline $\begin{array}{l}\text { Griegos } 4 \\
(218-804)\end{array}$ & 24,810 & 0.0025 & \\
\hline $\begin{array}{l}\text { Montaño } 6 \\
(558-563)\end{array}$ & 13,540 & 0.0011 & \\
\hline
\end{tabular}

${ }^{1}$ Storage coefficients not representative of the pumped well; therefore, they are not presented.

trend changes again and remains constant to the end of pumping. This last trend change also suggests that another recharge boundary was intercepted. Total drawdown at the end of pumping in the Griegos 1 well was about 64 feet (fig. 8A).

Results of the computer-assisted type-curve matching for the Griegos 1 well are shown in figure 8. The Theis (1935) solution was used to interpret the time-drawdown data for the pumped well, resulting in a transmissivity value of 10,570 feet squared per day (fig. 8B; table 2). A storage coefficient cannot be determined using time-drawdown data from the pumped well.

The semi-log plot for the time-drawdown data collected from the Griegos 4 well shows three trends as the cone of depression reaches the well and expands beyond it (fig. 9A). After the initial non-equilibrium drawdown effects are registered during the initial 800 minutes of pumping, the trend from about 800 to 9,000 minutes of pumping represents the migration of the cone of depression through a rather homogeneous part of the aquifer system. The trend change to a more horizontal line from 9,000 minutes to the end of the test represents a reduction of drawdown that suggests that the cone intercepted some type of a recharge boundary. Total drawdown recorded at the end of pumping was about 4.20 feet in Griegos 4. The lithologic log for the Griegos 4 well (pl. 1) shows approximately one-third of the screened interval completed in sandy clay. This large thickness of finer grained material could cause some of the small trend perturbations shown around 10,000 minutes and after 40,000 minutes after the start of pumping (fig. 9B).
Results of the computer-assisted type-curve matching for the Griegos 4 well are shown in figure 9. The Moench (1985) solution provided a transmissivity value of 24,810 feet squared per day and a storage coefficient of 0.0025 (fig. 9; table 2).

\section{Montaño 6 Piezometer Site}

The semi-log plot for the time-drawdown data collected from the Montaño 6 piezometer site (558- to 563-foot completion) shows four trends as the cone of depression reached the piezometer and expanded beyond it (fig. 10A). After the initial non-equilibrium effects are registered during the initial 100 minutes of pumping, the trend from about 100 to about 2,300 minutes of pumping represents the migration of the cone of depression through a rather homogeneous part of the aquifer system. The trend change to a more horizontal line from about 2,300 to about 12,500 minutes of pumping represents a reduction of drawdown that suggests that the cone intercepted some type of recharge boundary. Similarly, the trend change to an even more horizontal line from about 12,500 minutes to the end of the test suggests that another recharge boundary was intercepted. Total drawdown at the end of pumping in the 558- to 563-foot completed piezometer at the Montaño 6 piezometer site was about 11 feet (fig. 10B).

The computer-assisted type-curve matching solution for the Montaño 6 piezometer site resulted in an estimated transmissivity of 13,540 feet squared per day and a storage coefficient of 0.0011 (fig. 10; table 2). The transmissivity value obtained from the Montaño 6 piezometer site compares favorably with that obtained for the Griegos 1 well (table 2). 

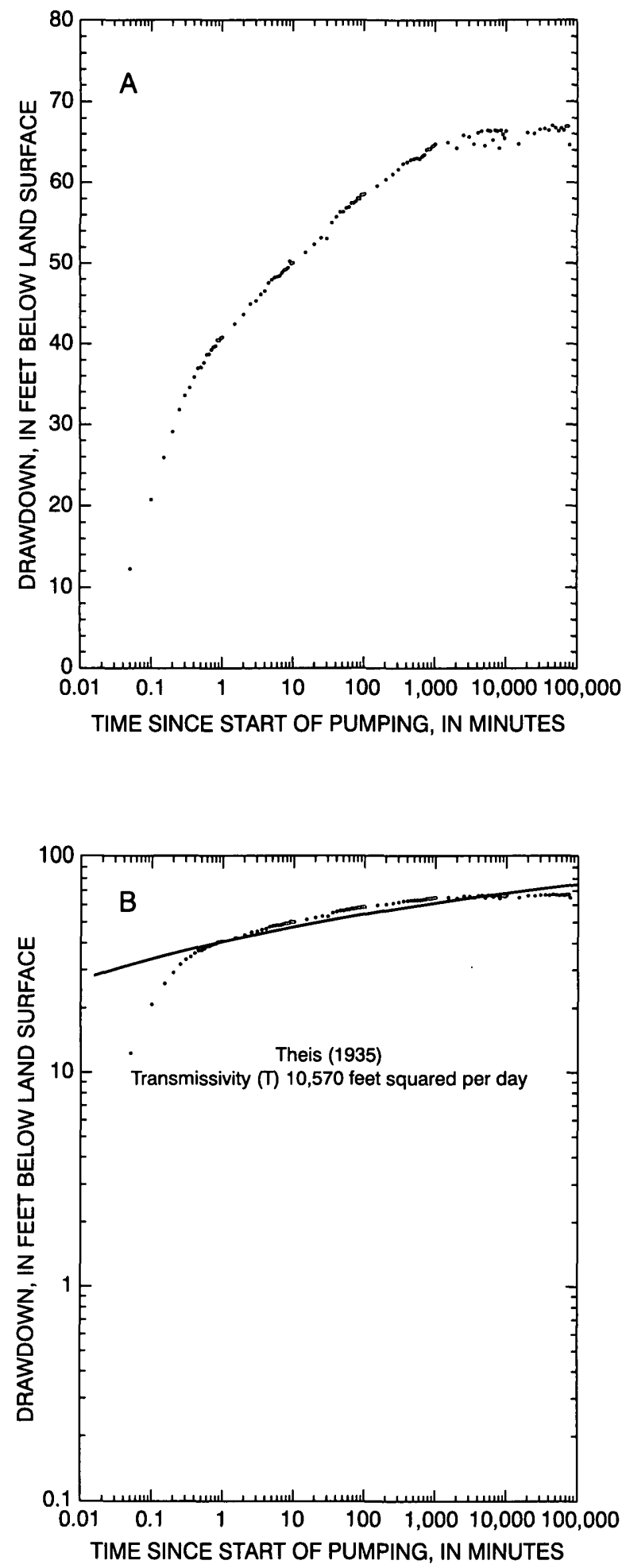

Figure 8. Semi-log plot and computer-assisted type-curve matching from the Griegos 1 production well. 

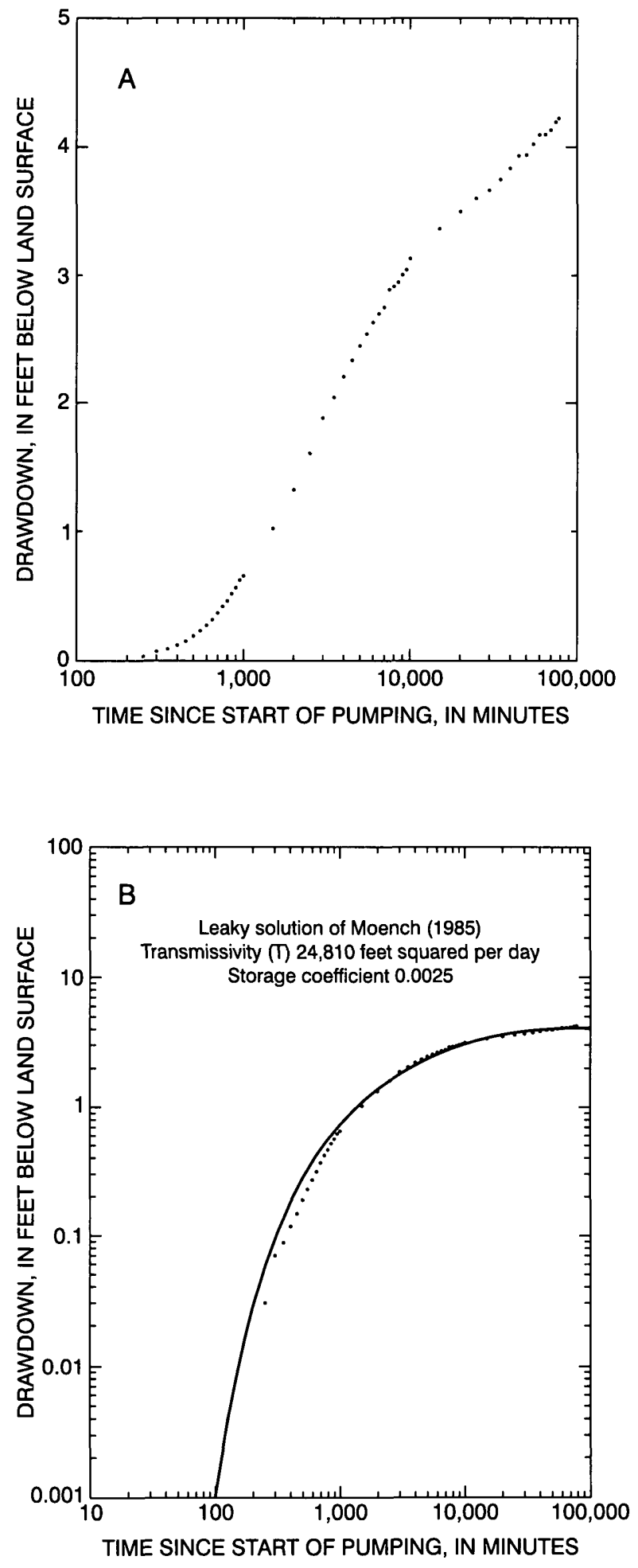

Figure 9. Semi-log plot and computer-assisted type-curve matching from the Griegos 4 production well. 

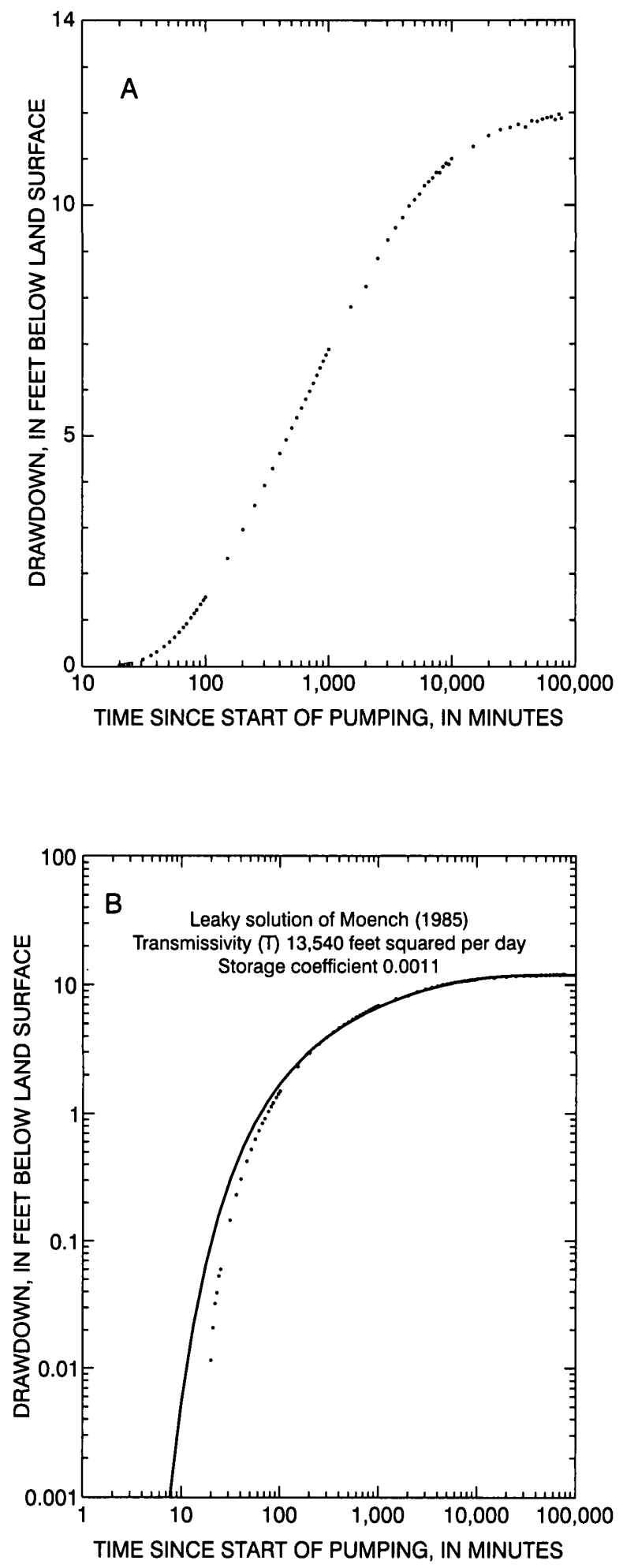

Figure 10. Semi-log plot and computer-assisted type-curve matching from the Montaño 6 piezometer site, 558- to 563-foot completion. 


\section{SUMMARY}

During the winter of 1994-95, a long-term aquifer test was conducted to further define aquifer properties in the area of the Griegos well field. The observation well and piezometer network consisted of nine monitoring sites (totaling 22 instrumented wells and piezometers) that allowed for the continuous collection of hydraulic-head data. Data collection began in October 1994, when production of all nearby City production wells was stopped. In addition to the collection of hydraulic-head data, a borehole extensometer was installed in November 1994 to monitor aquifer-system compaction resulting from ground-water withdrawal. On January 4, 1995, the Griegos 1 well (the pumped well) was turned on and pumped for about 54 days at an average pumping rate of 2,331 gallons per minute. Data collection continued for the duration of the pumping period and through the end of the 30-day recovery period.

At the end of the recovery period, well-bore video and flowmeter surveys were conducted along the screened interval of the Griegos 1 well. Results of these two surveys allowed for a greater understanding of the production zones of the screened interval and location of the more highly productive zones of the aquifer system near the Griegos 1 well. The well-bore video survey indicated that the screen in Griegos 1 was encrusted with mineralization below 640 feet below land surface. Results of the flowmeter survey indicated no significant flow to the wellbore below a depth of 640 feet and the location of the most productive zones at about 360-380 and 540-560 feet below land surface.

Data collected by the extensometer near the Montaño 6 piezometer site during the aquifer test quantify vertical strain of the aquifer system during the test. The estimated inelastic compaction of the lowpermeability beds during the 54 days of pumping was about 0.02 inch over the 1,033-foot interval measured by the extensometer. By using the average drawdown recorded in the piezometers at the Montaño 6 piezometer site, a specific storage of $2 \times 10^{-6}$ foot $^{-1}$ ( $6 \times 10^{-6}$ meter $^{-1}$ ) over the 1,033 feet spanned by the extensometer was calculated.

Aquifer properties in the monitoring wells were estimated using an analytical solution that combines the leaky aquifer theory and effects of storage within the confining units with a theory of flow to a largediameter well. The curve-matching efforts were performed using the computer software AQTESOLV on data collected from the Griegos 1 and 4 wells and one piezometer completed in the production zone. Estimated transmissivity and storage coefficient for the Griegos 4 well are 24,810 feet squared per day and 0.0025 , respectively, and for a piezometer completed in the production zone are 13,540 feet squared per day and 0.0011 , respectively.

\section{SELECTED REFERENCES}

Anderholm, S.K., and Bullard, T.F., 1987, Description of piezometer nests and water levels in the Rio Grande valley near Albuquerque, Bernalillo County, New Mexico: U.S. Geological Survey Open-File Report 87122, $51 \mathrm{p}$.

Batu, B., 1998, Aquifer hydraulics: New York, John Wiley \& Sons, Inc., 727 p.

Connell, S.D., Allen, B.D., and Hawley, J.W., 1998, Subsurface stratigraphy of the Santa Fe Group from borehole geophysical logs, Albuquerque, New Mexico: Socorro, New Mexico Bureau of Mines and Mineral Resources, New Mexico Geology, v. 20, no. 1, p. 2-7.

Cooper, H.H., and Jacob, C.E., 1946, A generalized graphical method for evaluating formation constants and summarizing well field history: American Geophysical Union Transactions, v. 27, p. 526-534.

Groundwater Management, Inc., 1988, Pumping test data analysis, Griegos well field, City of Albuquerque, New Mexico: Consultant report, Kansas City, Kans., 22 p.

Hanson, R.T., and Nishikawa, Tracy, 1996, Combined use of flowmeter and time-drawdown data to estimate hydraulic conductivities in layered aquifer systems: Ground Water, v. 34, no. 1, p. 84-94.

Hantush, M.S., 1960, Modification of the theory of leaky aquifers: Journal of Geophysical Research, v. 65, no. 11, p. 3713-3725.

Hantush, M.S., and Jacob, C.E., 1955, Non-steady radial flow in an infinite leaky aquifer: American Geophysical Union Transactions, v. 36, p. 95-100.

Hawley, J.W., 1996, Hydrogeologic framework of potential recharge areas in the Albuquerque Basin, central New Mexico, in Hawley, J.W., and Whitworth, T.M., eds., Hydrogeology of potential recharge areas and hydrogeochemical modeling of proposed artificialrecharge methods in basin- and valley-fill aquifer systems, Albuquerque Basin, New Mexico: Socorro, New Mexico Bureau of Mines and Mineral Resources Open-File Report 402-D, chap. 1.

Hawley, J.W., and Haase, C.S., 1992, Hydrogeologic framework of the northern Albuquerque Basin: Socorro, New Mexico Bureau of Mines and Mineral Resources Open-File Report 387, variously paged. 
Heywood, C.E., 1998, Piezometric-extensometeric estimations of specific storage in the Albuquerque Basin, New Mexico, in Borchers, J.W., ed., Land subsidence case studies and current research: Belmont, Calif., Star Publishing Co., p. 435-440.

Kernodle, J.M., McAda, D.P., and Thorn, C.R., 1995, Simulation of ground-water flow in the Albuquerque Basin, central New Mexico, 1901-1994, with projections to 2020: U.S. Geological Survey WaterResources Investigations Report 94-4251, 114 p.

Lohman, S.W., 1979, Ground-water hydraulics: U.S. Geological Survey Professional Paper 708, 70 p.

McAda, D.P., 2001, Simulation of a long-term aquifer test conducted near the Rio Grande, Albuquerque, New Mexico: U.S. Geological Survey Water-Resources Investigations Report 99-4260, 66 p.

Moench, A.F., 1985, Transient flow to a large-diameter well in an aquifer with storative semiconfining layers: Water Resources Research, v. 21, no. 8, p. 1121-1131.

Molz, F.J., Morin, R.H., Hess, A.E., Melville, J.G., and Güven, O., 1989, The impeller meter for measuring aquifer permeability variations - and comparison with other tests: Water Resources Research v. 25, no. 7, p. 1677-1683.

Neuman, S.P., and Witherspoon, P.A., 1972, Field determination of the hydraulic properties of leaky multiple aquifer systems: Water Resources Research, v. 8, no. 5, p. 1284-1298.

Ortiz, David, and Lange, K.M., 1996, Water resources data, New Mexico, water year 1995: U.S. Geological Survey Water-Data Report NM-95-1, 628 p.

Rehfeldt, K.R., Hufschmied, P., Gelhar, L.W., and Schaefer, M.E., 1989, Measuring hydraulic conductivity with the borehole flowmeter: Palo Alto, Calif., Electric Power Research Institute Topical Report Number EPRI EN6511 , variously paged.

Riley, F.S., 1970, Analysis of borehole extensometer data from central California, in Tison, L.J., ed., Land subsidence: International Association of Hydrological Sciences Publication 89, v. 2, p. 423-431.

1986, Developments in borehole extensometry, in Johnson, A.I., Carbognin, L., and Ubertini, L., eds., Land subsidence: International Association of Hydrological Sciences Publication 151, p. 169-186.

Theis, C.V., 1935, Relation between lowering the piezometric surface and the rate and duration of discharge of a well using ground-water storage: American Geophysical Union Transactions, pt. 2, p. 519-524.

Thorn, C.R., McAda, D.P., and Kernodle, J.M., 1993, Geohydrologic framework and hydrologic conditions in the Albuquerque Basin, central New Mexico: U.S. Geological Survey Water-Resources Investigations Report 93-4149, 106 p.
U.S. Geological Survey, 1982, Measurement and computation of streamflow--Volume 1. Measurement of stage and discharge: U.S. Geological Survey WaterSupply Paper 2175, $284 \mathrm{p}$.

Walton, W.C., 1962, Selected analytical methods for well and aquifer evaluation: Champaign, Illinois State Water Survey Bulletin 49, 81 p. 
TECHNICAL SUPPORT

James Basler, Hydrologic Technician

EDITORIAL, GRAPHICS, AND TEXT PREPARATION TEAM

Harriet R. Allen, Editor

Darla Straka, Scientific Illustrator

Mary Montaño, Editorial Assistant
TECHNICAL REVIEWERS OR ADVISOR

Kenneth R. Watts, Hydrologist, Pueblo, Colorado

Ralph W. Wilcox III, Hydrologist, Albuquerque, New Mexico

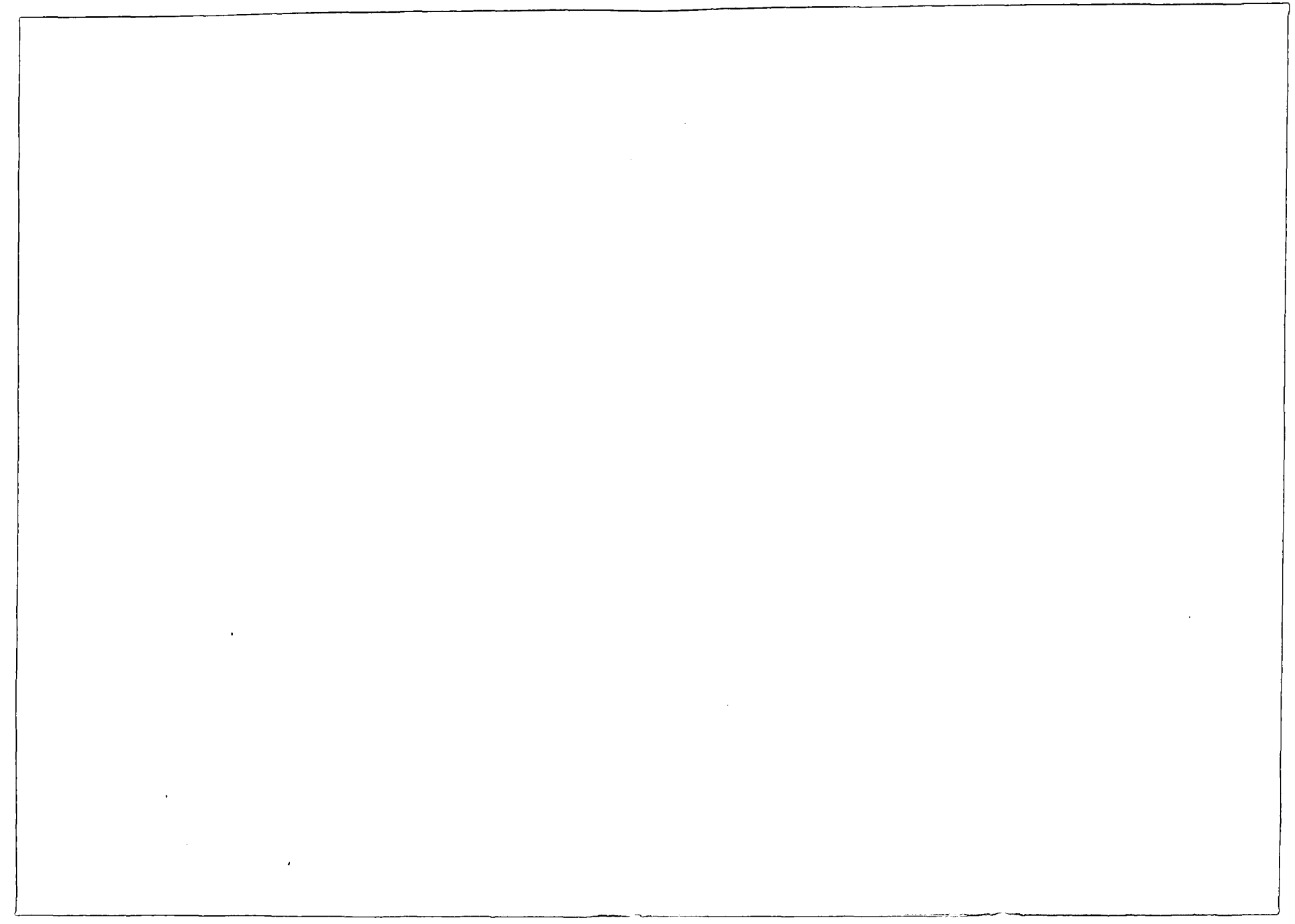


U.S. Department of the Interior

U.S. Geological Survey, WRD

5338 Montgomery Blvd. NE, Suite 400

Albuquerque, NM 87109-1311

\section{BOOK RATE}

